\title{
Metal oxide nanoparticles interact with immune cells and activate different cellular responses
}

\author{
This article was published in the following Dove Press journal: \\ International Journal of Nanomedicine \\ 14 September 2016 \\ Number of times this article has been viewed
}

\author{
Rosana Simón-Vázquez \\ Tamara Lozano-Fernández \\ Angela Dávila-Grana \\ Africa González-Fernández \\ Immunology Laboratory, Biomedical \\ Research Center (CINBIO) and \\ Institute of Biomedical Research \\ of Ourense-Pontevedra-Vigo (IBI), \\ University of Vigo, Campus Lagoas \\ Marcosende, Vigo, Pontevedra, Spain
}

Correspondence: Rosana Simón-Vázquez; Africa González-Fernández Immunology Laboratory, Biomedical Research Center (CINBIO) and Institute of Biomedical Research of OurensePontevedra-Vigo (IBI), University of Vigo, Campus Lagoas Marcosende, Vigo, Pontevedra, 36310, Spain

$\mathrm{Tel}+34986812625$

Fax +34986812556

Email rosana.simon@uvigo.es; africa@uvigo.es

\begin{abstract}
Besides cell death, nanoparticles (Nps) can induce other cellular responses such as inflammation. The potential immune response mediated by the exposure of human lymphoid cells to metal oxide $\mathrm{Nps}$ (moNps) was characterized using four different moNps $\left(\mathrm{CeO}_{2}, \mathrm{TiO}_{2}\right.$, $\mathrm{Al}_{2} \mathrm{O}_{3}$, and $\mathrm{ZnO}$ ) to study the three most relevant mitogen-activated protein kinase subfamilies and the nuclear factor kappa-light-chain-enhancer of the activated B-cell inhibitor, I $\mathrm{B} \alpha$, as well as the expression of several genes by immune cells incubated with these Nps. The moNps activated different signaling pathways and altered the gene expression in human lymphocyte cells. The $\mathrm{ZnO}$ Nps were the most active and the release of $\mathrm{Zn}^{2+}$ ions was the main mechanism of toxicity. $\mathrm{CeO}_{2} \mathrm{Nps}$ induced the smallest changes in gene expression and in the I $\mathrm{B} \alpha$ protein. The effects of the particles were strongly dependent on the type and concentration of the Nps and on the cell activation status prior to $\mathrm{Np}$ exposure.
\end{abstract}

Keywords: Jurkat, MAPK, NFאB, qPCR, inflammation, metabolism

\section{Introduction}

Exposure to different nanomaterials (NMs) has increased in recent years due to their presence in a large number of commercial products. The workplaces where these products are manufactured represent another potential source of accidental exposure to NMs. Metal oxide nanoparticles (moNps) are among the most widely used NMs, with several applications in industries such as cosmetics and paints. Due to the special physicochemical properties of the moNps, some of them have been proposed as biomedical agents, either alone or in combination with other materials. Examples include magnetic Nps for imaging applications and for hyperthermia, ${ }^{1} \mathrm{Al}_{2} \mathrm{O}_{3} \mathrm{Nps}$ as a coating agent for magnetic $\mathrm{Nps},{ }^{2}$ and $\mathrm{ZnO} \mathrm{Nps}$ as antibacterial or antitumoral agents. ${ }^{3}$ Moreover, the antioxidant properties of $\mathrm{CeO}_{2} \mathrm{Nps}$ are being explored for the treatment of diseases related to increased oxidative stress, such as Alzheimer and Parkinson. ${ }^{4-6}$ Likewise, the use of silver particles in nanoporous $\mathrm{TiO}_{2}$ and $\mathrm{Al}_{2} \mathrm{O}_{3}$ implants is another good example of the potential application of moNps in biomedicine. ${ }^{7}$ However, the cellular and molecular effects of many moNps have not been fully characterized, although some effects on cell death, genotoxicity, and the production of reactive oxygen species by them have been described. ${ }^{8-11}$ There has been a steady increase in the number of studies concerning gene expression and proteomic analysis, ${ }^{12-15}$ but more investigations are urgently needed, especially those involving a comparison of the effects induced by different Nps on immune cells and aimed at understanding the cellular pathways that are activated by these NMs.

When exposed to a stimulus, the immune cells may activate a variety of signaling pathways that induce different responses, such as proliferation, differentiation, 
migration, and inflammatory and immune responses. Mitogen-activated protein kinases (MAPKs) are a family of proteins that control many physiological processes in multicellular organisms ${ }^{16}$ and there are three particularly relevant subfamilies: extracellular signal-regulated kinases (ERKs), the p38 kinases, and the c-Jun amino-terminal kinases (JNKs), also called stress-activated protein kinases (SAPKs). While ERKs are mainly involved in the control of cell division, p38 kinases are MAPKs that are activated by inflammatory cytokines and environmental stress, while the JNKs are critical regulators of transcription. Indeed, members of the p38 and SAPK/JNK families generally induce apoptosis, whereas ERK has been involved in cell survival. ${ }^{17}$ In addition, the nuclear factor kappa-light-chain-enhancer of the activated B-cell (NFKB) family of transcription factors (TFs) are also key regulators of immune, inflammatory, and acute phase responses, and these TFs are also involved in the control of cell proliferation, apoptosis, and oncogenesis. ${ }^{18}$

The work described here involves a study of the activation of MAPK and NFKB caused by four different moNps $\left(\mathrm{CeO}_{2}\right.$, $\mathrm{TiO}_{2}, \mathrm{Al}_{2} \mathrm{O}_{3}$, and $\mathrm{ZnO}$ ) in a human $\mathrm{T}$-cell line. Two different concentrations of Nps were tested: 10 and $100 \mu \mathrm{g} / \mathrm{mL}$ for $\mathrm{CeO}_{2}, \mathrm{TiO}_{2}$, and $\mathrm{Al}_{2} \mathrm{O}_{3} \mathrm{Nps}$ and 5 and $50 \mu \mathrm{g} / \mathrm{mL}$ for $\mathrm{ZnO} \mathrm{Nps}$ due to their high cell toxicity, ${ }^{19}$ with an LD50 of $55 \mu \mathrm{g} / \mathrm{mL}$ in Jurkat. ${ }^{20}$ Moreover, the influence of the $\mathrm{Zn}^{2+}$ metal ion was studied by adding $\mathrm{ZnCl}_{2}$ salt to the cells because ion release and the subsequent loss of ion homeostasis in the cells has been proposed as a relevant mechanism associated with the toxicity of $\mathrm{ZnO} \mathrm{Nps}^{13,21,22}$

In addition to the release of ions, other $\mathrm{Np}$-specific effects have also been reported, ${ }^{23,24}$ including the triggering of several genes that lead to changes in distinct physiological processes such as metabolism or mitosis. It is well known that the previous status of the cell can have a marked influence on the signaling routes to be activated. For example, the activation of T cells through the T-cell receptor leads to the phosphorylation of the ERK protein in naïve cells, while the p38 protein is more affected in cells that have been previously antigen-primed. ${ }^{25}$ Moreover, activation of ERK induces the degradation of the signalosome, which impairs signaling, whereas p38 facilitates cell activation. ${ }^{25}$ For this reason, a well-known lymphocyte activator (phytohemagglutinin [PHA]) was also used to stimulate the T-cell line before their incubation with the moNps. In order to follow the activation of different intracellular pathways, quantitative PCR (qPCR) was carried out to study the expression of several genes related with processes such as apoptosis, inflammation, cell cycle progression, and metabolism.

\section{Materials and methods Nanoparticles}

The $\mathrm{Nps}\left(\mathrm{TiO}_{2}[3.59 \pm 0.94 \mathrm{~nm}], \mathrm{Al}_{2} \mathrm{O}_{3}[13.56 \pm 8.37 \mathrm{~nm}], \mathrm{CeO}_{2}\right.$ $[13.04 \pm 12.13 \mathrm{~nm}]$, and $\mathrm{ZnO}[36.16 \pm 18.27 \mathrm{~nm}])$ were supplied by PlasmaChem (Berlin, Germany) and Evonik Industries AG (Essen, Germany) as part of the Health Impact of Engineered Metal and Metal Oxide Nanoparticles: Response, Bioimaging and Distribution at Cellular and Body Level project (European Union's seventh framework program). The Np size was determined by high-resolution transmission electron microscopy, and all of the Nps were uncoated and free of surfactant. The transmission electron microscopy images and dynamic light scattering characterization have been described previously $^{26}$ and they are shown in Figure S1.

The Nps were resuspended in milli-Q water at $10 \mathrm{mg} / \mathrm{mL}$ and, after sonication, $10 \%$ fetal bovine serum was added to reduce the aggregation of the Nps. Finally, the Nps were diluted to the working concentration in cell culture medium. The concentrations tested were 10 and $100 \mu \mathrm{g} / \mathrm{mL}$ for all $\mathrm{Nps}$ except for the $\mathrm{ZnO} \mathrm{Nps}$, which were tested at 5 and $50 \mu \mathrm{g} / \mathrm{mL}$ due to toxicity issues, as explained in the "Introduction" section.

\section{Cells}

The Jurkat cell line was purchased from the American Type Culture Collection, Middlesex, UK. The cells were cultured in RPMI 1640 medium supplemented with 10\% fetal bovine serum and penicillin-streptomycin at $37^{\circ} \mathrm{C}$ in the presence of $5 \% \mathrm{CO}_{2}$ (Thermo Fisher Scientific, Waltham, MA, USA).

\section{Incubation of the Nps with the cells, preparation of the cell extracts, and Western blots}

Incubation of the Nps with Jurkat cells, preparation of the cell extracts, and Western blots were performed as described in a previous publication for a lung epithelial cell line. ${ }^{20}$ The same protocol was also used for the $\mathrm{Zn}^{2+}$ ions at 1,10 , and $100 \mu \mathrm{g} / \mathrm{mL}$.

For cell activation, PHA (Sigma-Aldrich Co., St Louis, MO, USA) was added to the culture medium at $8 \mu \mathrm{g} / \mathrm{mL}$ and the cells were incubated overnight. The cells were then washed by centrifugation $\left(266 \times g\right.$ at $4^{\circ} \mathrm{C}$ for 5 minutes) in a Sorvall ST 16R centrifuge (Thermo Fisher Scientific) and suspended in RPMI prior to the addition of Nps.

\section{qPCR studies of gene expression}

Changes in gene expression were determined by real-time PCR or qPCR, using TaqMan 96-well plates with predesigned 
assays (4418775, Signal Transduction Pathways) and the TaqMan Fast Advanced Master Mix (Thermo Fisher Scientific) run on a 7900HT Fast Real-Time PCR System (AB, Thermo Fisher Scientific). Jurkat cells were incubated with the Nps for 24 hours at $100 \mu \mathrm{g} / \mathrm{mL}$, except for the $\mathrm{ZnO}$ Nps where the concentration was 20 times lower $(5 \mu \mathrm{g} / \mathrm{mL})$, and RNA was extracted and purified with the GeneJet extraction kit (Thermo Fisher Scientific). Genomic DNA was removed using DNase I (RNA-free) and complementary DNAs (cDNAs) were synthesized using a Maxima First Strand cDNA Synthesis kit (Thermo Fisher Scientific). The amount of cDNA per plate and sample was calculated relative to glyceraldehyde 3-phosphate dehydrogenase using different dilutions of cDNA to check the optimal dilution and the qPCR data were analyzed using SDS 2.4 and RQ Manager 1.2.1 software (Thermo Fisher Scientific, Waltham, MA, USA). For each Np, two independent measurements were taken and the value of the relative quantification was averaged, with glyceraldehyde 3-phosphate dehydrogenase used as the internal control. Values with a high standard deviation or genes that were not amplified in one of the two experiments were not taken into account.

\section{Results}

\section{Differential expression of p-ERK, p-p38,} and $p-S A P K / J N K$ in the Jurkat cell line and the effect of prestimulation with PHA

The expression of $\mathrm{p}$-ERK $(1,2), \mathrm{p}$-p38, and $\mathrm{p}$-SAPK/JNK induced by the moNps was studied in nonactivated (-PHA) or activated (+PHA) Jurkat cells (Figures 1 and S2).

The $\mathrm{TiO}_{2}$ Nps induced a strong phosphorylation of ERK-1, mostly after 3 hours in nonstimulated cells. However, $\mathrm{CeO}_{2}$ and $\mathrm{ZnO}$ Nps induced higher levels of the phosphorylated protein in PHA-stimulated cells than in nonstimulated cells, although in all cases, the Nps induced protein activation. The $\mathrm{Al}_{2} \mathrm{O}_{3}$ Nps produced small changes compared to the controls irrespective of whether or not the cells had been prestimulated with PHA.

Regarding p-p38, the strongest phosphorylation of this protein was induced by $\mathrm{ZnO}$ Nps (Figures 1 and S2). Nevertheless, the $\mathrm{CeO}_{2}$ and $\mathrm{TiO}_{2}$ Nps induced high levels of phosphorylation in PHA-stimulated cells, while activation of $\mathrm{p} 38$ protein was not observed in the cells exposed to $\mathrm{Al}_{2} \mathrm{O}_{3} \mathrm{Nps}$.

Similarly, activation of p-SAPK/JNK was not detected after 1 hour in the presence of any of the Nps analyzed, although both phosphoproteins were detected after 3 hours in the presence of the ZnO Nps (Figures 1 and S2). Prestimulation with PHA did not have any significant effect on the phosphorylation of this protein.
The activation of the MAPKs was dose-dependent and at a tenfold lower concentration. p38 and SAPK/JNK were only activated when the cells were incubated with $\mathrm{ZnO}$ Nps (Figure S3).

\section{Expression of the NFאB inhibitor, $I \kappa B \alpha$, in the Jurkat cell line}

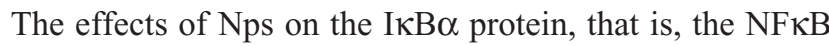
inhibitor, were characterized in the Jurkat cell line (Figures 1 and S2) and all of the moNps induced changes in this protein at 3 hours.

After 1 hour, the $\mathrm{Al}_{2} \mathrm{O}_{3} \mathrm{Nps}$ had increased the expression of this protein and this effect was even more marked at 3 hours; in contrast, the other Nps did not have any effect on unstimulated (-PHA) cells at short times, but a decrease in the expression of this I $\mathrm{KB} \alpha$ protein was observed at 3 hours in both unstimulated and stimulated cells, which indicates activation of the NFKB nuclear factor under these conditions.

Exposure of the Jurkat cells to a tenfold lower concentration of Nps for 3 hours led to I $\kappa \mathrm{B} \alpha$ degradation only in the case of $\mathrm{ZnO}$ Nps (Figure S3), both in unstimulated and prestimulated cells. A weak effect was also observed with the $\mathrm{TiO}_{2} \mathrm{Nps}$.

The activation induced by PHA alone led to degradation of $\mathrm{I} \kappa \mathrm{B} \alpha$ in the cells, but in combination with the Nps, this effect was even more marked.

\section{Effect of $\mathrm{Zn}^{2+}$ ions on the activation pathway induced by $\mathrm{ZnO} \mathrm{Nps}$}

It has been reported that $\mathrm{ZnO} \mathrm{Nps}$ are highly soluble compared to other moNps, but there is discrepancy in the literature concerning the solubility of these Nps in physiological media. $22,27,28$

In order to assess whether the effect induced by $\mathrm{ZnO} \mathrm{Nps}$ on Jurkat cells was due to the $\mathrm{Np}$ itself or to the $\mathrm{Zn}^{2+}$ ions released by the particles, the cells were exposed to $\mathrm{ZnCl}_{2}$ salt at three different concentrations $\left(1,10\right.$, and $\left.100 \mu \mathrm{g} / \mathrm{mL} \mathrm{Zn}^{2+}\right)$ and the MAPK and NFKB activation was assessed in Western blots.

It can be seen from Figures 2 and $\mathrm{S} 4$ that phosphorylation of p38 was enhanced at concentrations of 10 and $100 \mu \mathrm{g} / \mathrm{mL}$ of $\mathrm{Zn}^{2+}$ irrespective of the pretreatment of cell with PHA. The MAPK pathway was the most sensitive to this metal. Indeed, p-p38 could be detected 1 hour after exposure to $1 \mu \mathrm{g} / \mathrm{mL}$ of $\mathrm{Zn}^{2+}$. These results are similar to those obtained with $\mathrm{ZnO}$ Nps $(5 \mu \mathrm{g} / \mathrm{mL})$, which induced p-p38 under almost all of the conditions tested (Figure S3).

SAPK/JNK phosphorylation was detected after both 1 and 3 hours in the presence of $\mathrm{Zn}^{2+}$ ions at $100 \mu \mathrm{g} / \mathrm{mL}$ and after 3 hours at $10 \mu \mathrm{g} / \mathrm{mL}$ (Figures 2 and S4). Similarly, a low concentration of the $\mathrm{Zn}^{2+}$ ions $(1 \mu \mathrm{g} / \mathrm{mL})$ did not induce 

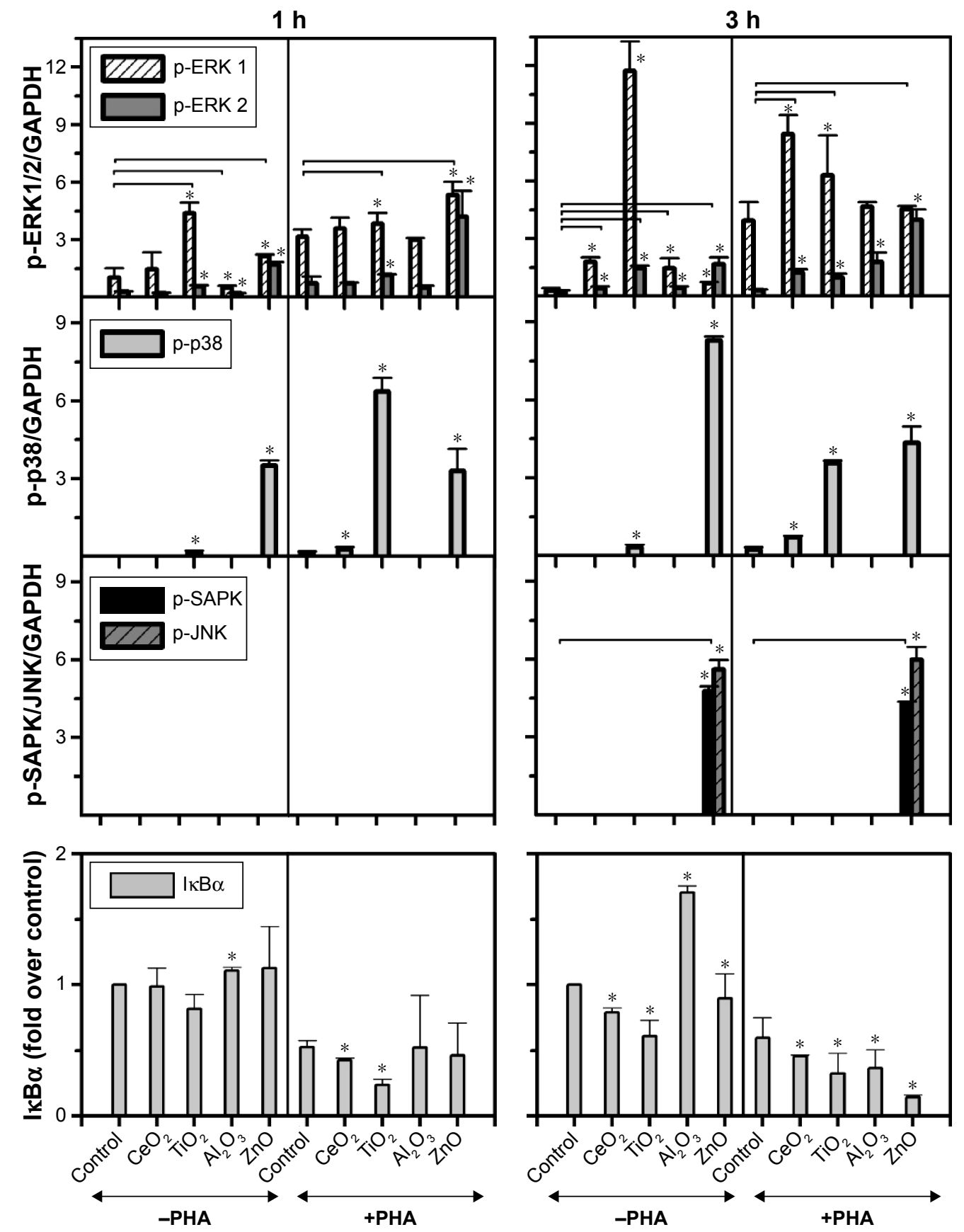

Figure I Expression of p-ERK (I,2), p-p38, p-SAPK/JNK, and I $\mathrm{KB} \alpha$ in Jurkat cells incubated with $\mathrm{CeO}_{2}, \mathrm{TiO}_{2}, \mathrm{Al}_{2} \mathrm{O}_{3}$, and $\mathrm{ZnO} \mathrm{Nps}$

Notes: The cells were tested in the presence (+PHA) or absence (-PHA) of PHA to assess the effect of lymphocyte preactivation on the cell response to the Nps. GAPDH was used as a loading control and two different times were tested ( $I$ and 3 hours). The protein was quantified and the difference in the protein levels is shown. The bars represent the average intensity normalized to the control sample and the error bars represent the standard deviation. *Statistically significant difference $(P<0.05)$ in the level of protein compared with the control (sample without Nps). The horizontal lines represent the treated samples that are statistically different from the control sample for both proteins studied. All Nps were tested at $100 \mu \mathrm{g} / \mathrm{mL}$, except for $\mathrm{ZnO}(50 \mu \mathrm{g} / \mathrm{mL})$.

Abbreviations: ERK, extracellular signal-regulated kinase; GAPDH, glyceraldehyde 3-phosphate dehydrogenase; h, hour; IкB $\alpha$, nuclear factor kappa-light-chain-enhancer of the activated B-cell inhibitor; JNK, c-Jun amino-terminal kinase; Nps, nanoparticles; PHA, phytohemagglutinin; SAPK, stress-activated protein kinase.

phosphorylation of these kinases and the pretreatment of cells with PHA did not alter their phosphorylation.

In the case of ERK, only the highest concentration of the $\mathrm{Zn}^{2+}$ ion $(100 \mu \mathrm{g} / \mathrm{mL})$ induced phosphorylation in prestimulated and unstimulated Jurkat cells after both 1 and 3 hours (Figures 2 and S4). This result is consistent with those obtained for the $\mathrm{ZnO}$ Nps $(50 \mu \mathrm{g} / \mathrm{mL})$ under almost all of the conditions studied (Figures 1 and S2).

As far as the NFKB pathway activation is concerned, the pattern was similar to that observed for $\mathrm{p}-\mathrm{SAPK} / \mathrm{JNK}$ (Figures 2 and S4). Degradation of I $\mathrm{B} \alpha$ was detected after 1 hour at the highest $\mathrm{Zn}^{2+}$ concentration and after 3 hours at 

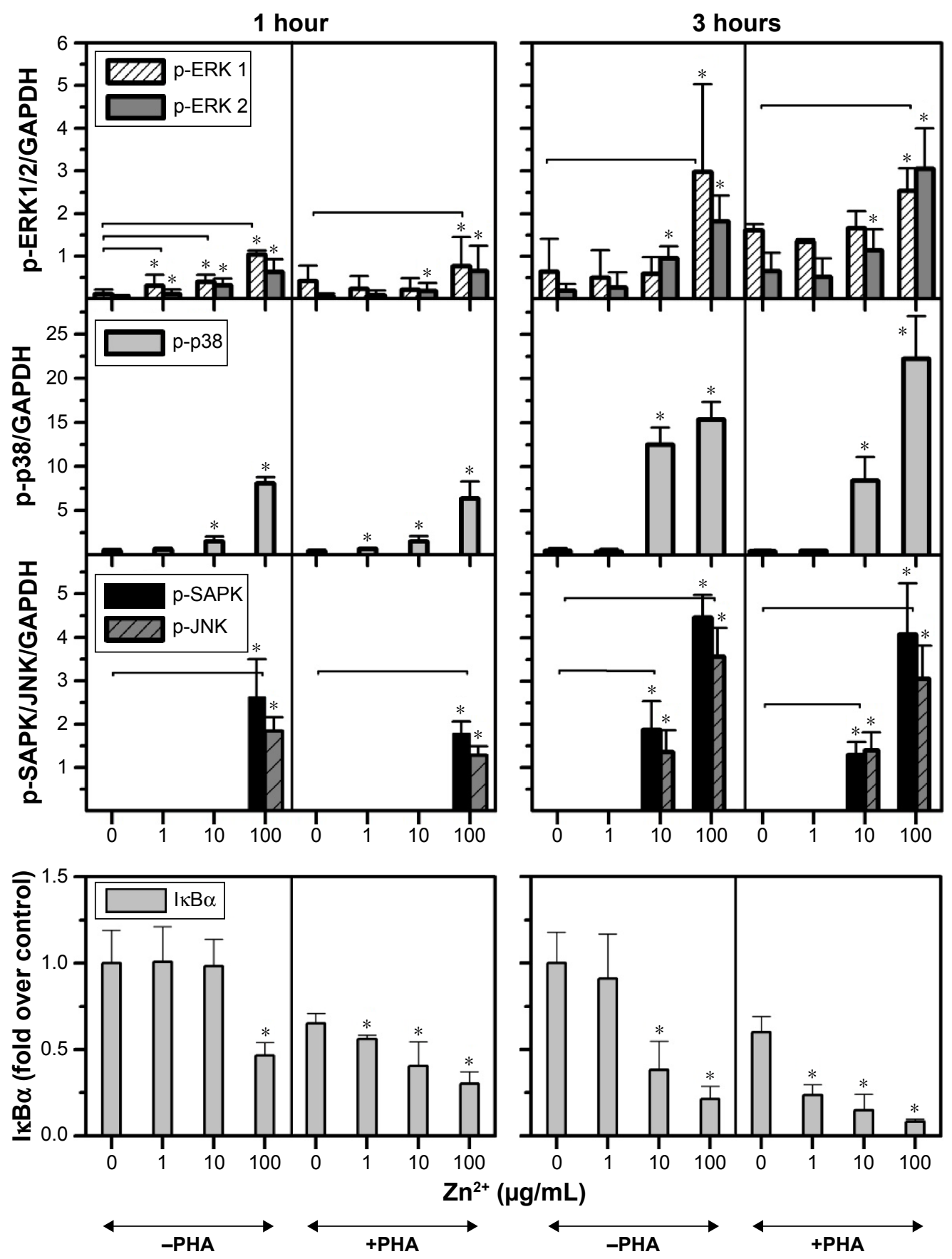

Figure 2 Influence of the $\mathrm{Zn}^{2+}$ ion concentration on the activation of MAPK and NFKB in Jurkat cells.

Notes: The influence of ion release on the toxicity induced by $\mathrm{ZnO}$ nanoparticles was studied by incubating Jurkat cells, prestimulated (+PHA) or not (-PHA) with PHA, with three different concentrations of $\mathrm{ZnCl}_{2}$ salt as the source of $\mathrm{Zn}^{2+}$ ions (I, 10 , and $\left.100 \mu \mathrm{g} / \mathrm{mL}\right)$, and measuring the activation of ERK (I,2), P38, SAPK/JNK, and the NFKB pathways at I and 3 hours. *Statistically significant difference $(P<0.05)$ in the level of protein compared with the control (untreated sample). The horizontal lines represent the treated samples that are statistically different from the control sample for both proteins studied.

Abbreviations: ERK, extracellular signal-regulated kinase; GAPDH, glyceraldehyde 3-phosphate dehydrogenase; IאB $\alpha$, NFKB inhibitor; JNK, c-Jun amino-terminal kinase; MAPK, mitogen-activated protein kinase; NFKB, nuclear factor kappa-light-chain-enhancer of the activated B-cell; PHA, phytohemagglutinin; SAPK, stress-activated protein kinase.

concentrations of both 10 and $100 \mu \mathrm{g} / \mathrm{mL}$. The lowest concentration of $\mathrm{Zn}^{2+}(1 \mu \mathrm{g} / \mathrm{mL})$ was also able to induce IкB $\alpha$ degradation in prestimulated cells. It is important to note that PHA treatment induced some degradation of this protein, but the combination of PHA with the Nps or $\mathrm{Zn}^{2+}$ ion further enhanced activation of the NFKB pathway.

\section{Expression of genes in signal transduction} pathways in the Jurkat cell line

The changes in the expression of a group of selected genes that participate in different cell functions were analyzed. The genes studied are summarized in Table 1 and those genes that showed the highest relative changes, either upregulated or 
Table I Changes in the expression of selected genes in the Jurkat cell line

\begin{tabular}{|c|c|c|c|c|c|c|}
\hline $\mathrm{CeO}_{2}$ & $\mathrm{TiO}_{2}$ & $\mathrm{Al}_{2} \mathrm{O}_{3}$ & Zno & Gene & Name & Function \\
\hline & & 3.17 & 0.84 & ACTB & Beta-actin & Cell structure and motility \\
\hline & 0.76 & 2.24 & & $B 2 M$ & Beta-2-microglobulin & Component of the MHC class I \\
\hline 1.55 & & 3.84 & & $B A X$ & $\mathrm{BCL} 2$-associated $\mathrm{X}$ protein & Apoptotic activator \\
\hline 1.77 & & 6.33 & & BCL2AI & $\mathrm{BCL2}$-related protein $\mathrm{Al}$ & Anti-apoptotic \\
\hline \multirow[t]{2}{*}{0.95} & 0.94 & 2.69 & 1.33 & BIRC2 & Baculoviral IAP repeat-containing 2 & Apoptotic inhibitor \\
\hline & 0.70 & 3.58 & 1.23 & BIRC3 & Baculoviral IAP repeat-containing 3 & Apoptotic inhibitor \\
\hline 1.37 & 0.23 & I.II & & CCL2 & Chemokine ( $\mathrm{C}-\mathrm{C}$ motif) ligand 2 & Chemotactic factor \\
\hline 0.70 & 4.97 & 0.80 & & CCNDI & Cyclin DI & Cell cycle regulation \\
\hline \multirow[t]{6}{*}{2.44} & 2.51 & 2.73 & 3.79 & CDKNIA & Cyclin-dependent kinase inhibitor IA & Cell cycle GI phase arrest \\
\hline & & 3.21 & 0.71 & $C D K N / B$ & Cyclin-dependent kinase inhibitor IB & Cell cycle progression at GI \\
\hline & 1.14 & 3.33 & 0.85 & CEBPB & CCAAT/enhancer-binding protein beta & Transcription factor \\
\hline & & 0.99 & 19.39 & CYPI9AI & Cytochrome P450, family I9-A, I & Drug metabolism \\
\hline & 1.44 & 6.50 & 0.24 & FASN & Fatty acid synthase & Lipid metabolism \\
\hline & 1.36 & 3.31 & 0.77 & GADD45A & Growth arrest and DNA-damage-inducible, alpha & Cell cycle arrest, DNA repair \\
\hline 0.72 & 0.88 & 0.97 & 0.41 & GYSI & Glycogen synthase I & Glycogen metabolism \\
\hline 1.17 & 1.21 & 2.44 & 1.02 & $I K B K B$ & $\begin{array}{l}\text { Inhibitor of } \kappa \text { light polypeptide gene enhancer in } \\
B \text { cells, kinase beta }\end{array}$ & NF-kappa-B signaling pathway \\
\hline \multirow[t]{2}{*}{1.29} & 0.73 & 15.28 & 3.51 & IL-2 & Interleukin-2 & T-cell clonal expansion. ThI \\
\hline & 0.24 & 3.41 & & IL-8 & Interleukin-8 & Chemokine \\
\hline 0.83 & 1.32 & 2.27 & & JUN & Jun proto-oncogene & Transcription factor \\
\hline \multirow[t]{3}{*}{1.82} & 2.05 & 6.65 & & MDM2 & P53 E3 ubiquitin protein ligase homologue & Inhibitor of $\mathrm{p} 53$ \\
\hline & 4.72 & 5.12 & & NAIP & NLR family, apoptosis inhibitory protein & Apoptotic inhibitor \\
\hline & 0.83 & 3.05 & & PPARG & Peroxisome proliferator-activated receptor gamma & $\begin{array}{l}\text { Nuclear receptor/glucose } \\
\text { homeostasis }\end{array}$ \\
\hline 0.72 & 0.90 & 1.38 & 0.38 & PRKCE & Protein kinase C, epsilon & Cell adhesion/cell cycle \\
\hline \multirow[t]{2}{*}{1.01} & 1.42 & 3.73 & 0.50 & PTCHI & Patched I & Receptor/tumor suppressor \\
\hline & & 2.56 & 12.03 & RBPI & Retinol-binding protein I, cellular & $\begin{array}{l}\text { Carrier protein/retinol } \\
\text { transport }\end{array}$ \\
\hline 0.59 & 1.56 & 1.64 & 0.39 & VEGFA & Vascular endothelial growth factor $\mathrm{A}$ & Growth factor \\
\hline
\end{tabular}

Notes: Jurkat cells were incubated for 24 hours with $\mathrm{CeO}_{2}, \mathrm{TiO}_{2}, \mathrm{Al}_{2} \mathrm{O}_{3}$, and $\mathrm{ZnO} \mathrm{Nps}$. The values in the table represent the relative quantification with respect to the control sample (in the absence of $\mathrm{Nps}$ ). The genes upregulated or downregulated (at least fourfold or more) are highlighted in bold.

Abbreviations: NF, nuclear factor; Nps, nanoparticles; NLR, NOD-like receptors.

downregulated, are highlighted. Interestingly, only one gene was upregulated in all of the samples, namely, the $C D K N 1 \mathrm{~A}$ (cyclin-dependent kinase inhibitor 1A), which is involved in cell cycle G1 phase arrest.

In comparison with the $\mathrm{CeO}_{2} \mathrm{Nps}$, which did not induce major changes, each of the other Nps modified the expression of some genes. For example, $\mathrm{Al}_{2} \mathrm{O}_{3} \mathrm{Nps}$ induced the expression of some antiapoptotic genes (BCL2A1 and $N A I P$ ) and cytokines ( $I L-2$ and $I L-8)$, as well as upregulated others: $C E B P B$, a TF involved in inflammation and immune responses; $M D M 2$, encoding an inhibitor of the $\mathrm{p} 53$ protein (and is transcriptionally regulated by this protein); and the FASN and RBPl genes, which are related to lipid metabolism and cholesterol homeostasis, respectively.

In cells exposed to the $\mathrm{ZnO} \mathrm{Nps}$, the expression of $R B P I$ and $I L-2$ was upregulated, as was that of the CYP19A1 gene involved in xenobiotic metabolism and redox reactions, while the expression of the FASN gene was downregulated. In the case of $\mathrm{TiO}_{2} \mathrm{Nps}$, the CCND1 gene involved in regulating the G1/S cell cycle transition was upregulated, as were the NAIP (an inhibitor of apoptosis) and $M D M 2$ genes, while both the $I L-2$ and $I L-8$ cytokine genes and the $C C L 2$ chemokine gene were downregulated.

\section{Discussion}

Two of the main activation pathways (MAPK and NFKB) were studied to test the possible cellular response induced by four different moNps $\left(\mathrm{CeO}_{2}, \mathrm{TiO}_{2}, \mathrm{Al}_{2} \mathrm{O}_{3}\right.$, and $\left.\mathrm{ZnO}\right)$ in Jurkat cells (derived from human T lymphocytes).

$\mathrm{ZnO} \mathrm{Nps}$ at $50 \mu \mathrm{g} / \mathrm{mL}$ activated the three MAPKs. p38 and SAPK/JNK were also activated in the presence of $5 \mu \mathrm{g} / \mathrm{mL} \mathrm{ZnO} \mathrm{Nps}$, probably due to the enhanced susceptibility of the lymphoid cells to these Nps. Indeed, ZnO Nps were the only ones tested that activated SAPK/JNK, which is mainly involved in apoptosis, ${ }^{29}$ and this finding is consistent with the cytotoxic effects previously observed for these Nps in several cell lines, ${ }^{19}$ including Jurkat cells. ${ }^{20}$ 
$\mathrm{CeO}_{2}$ and $\mathrm{TiO}_{2} \mathrm{Nps}(100 \mu \mathrm{g} / \mathrm{mL})$ activated $\operatorname{ERK}(1,2)$ and p38, while $\mathrm{Al}_{2} \mathrm{O}_{3}$ Nps only induced ERK $(1,2)$ activation after 3 hours of exposure at the same concentration. This activation was dose-dependent as it was not produced by any of these Nps at low concentration $(10 \mu \mathrm{g} / \mathrm{mL})$. Prestimulation of Jurkat cells with PHA modified the extent, but not the pattern of MAPK activation. Only ERK was activated by prestimulation with PHA, although this activation was weaker than that observed following exposure to the Nps. The combination of both treatments induced stronger phosphorylation, although there were some differences in terms of the time and/or protein level.

The toxicity induced by the $\mathrm{ZnO} \mathrm{Nps}$ in vitro could be mostly due to ion release, as suggested elsewhere. ${ }^{13,21,22}$ MAPK activation induced by $\mathrm{Zn}^{2+}$ ions in Jurkat cells involved the same pattern of $\mathrm{p} 38$ and SAPK/JNK phosphorylation at concentrations of 10 and $100 \mu \mathrm{g} / \mathrm{mL}$, but not at $1 \mu \mathrm{g} / \mathrm{mL}$. In fact, the highest concentration of $\mathrm{Zn}^{2+}$ salt induced earlier activation of SAPK/JNK than that observed with the $\mathrm{ZnO}$ Nps. As expected, the effects observed with the $\mathrm{ZnO} \mathrm{Nps}$ or the $\mathrm{Zn}^{2+}$ salt were dose-dependent and phosphorylation of ERK was only detected at the highest concentration of $\mathrm{Zn}^{2+}$ ions under all the conditions tested, while an effect of $\mathrm{ZnO}$ Nps on ERK phosphorylation was detected even at $50 \mu \mathrm{g} / \mathrm{mL}$.

The release of $\mathrm{Zn}^{2+}$ ions clearly plays an important role in the apoptosis and the cell pathways activated by $\mathrm{ZnO}$ Nps. Indeed, a similar pattern of MAPK was activated by $\mathrm{ZnO} \mathrm{Nps}$ and $\mathrm{Zn}^{2+}$ ions, although Np-specific effects may influence other pathways of activation or cell toxicity, as proposed previously. ${ }^{23,24}$

Moreover, the toxicity found in vitro is higher than the toxicity found in vivo due to the capacity of the tissues and organs to bind the free ions by forming $\mathrm{Zn}-\mathrm{S}$ bonds..$^{30} \mathrm{It}$ should be noted, however, that these altered sulfur-containing molecules could be a different source of toxicity.

Degradation of the I $\kappa \mathrm{B} \alpha$ inhibitor was studied as a marker

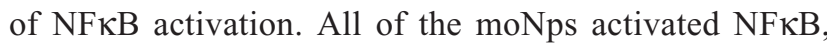
a pathway that is mainly related with inflammation and the immune response. Moreover, preincubation with PHA, an activator of this pathway, ${ }^{31}$ induced greater degradation of the protein when the cells were exposed to any of the moNps, except for the $\mathrm{Al}_{2} \mathrm{O}_{3} \mathrm{Nps}$, which induced an increase in the expression in unstimulated cells.

The strongest degradation was induced by the combination of PHA and $\mathrm{ZnO}$ at both concentrations studied, and for all the moNps, the effect was dose-dependent. Once again, the $\mathrm{Zn}^{2+}$ ions could activate this pathway even at the lowest concentration tested $(1 \mu \mathrm{g} / \mathrm{mL})$ in prestimulated Jurkat cells.

Lymphocytes were more susceptible than lung cells ${ }^{20}$ to the activation of these pathways, which clearly indicates that the type of cell is crucial regarding its behavior in response to Nps, a finding that is consistent with previous studies concerning differences in cell toxicity induced by NMs. ${ }^{29}$

In an effort to characterize other cellular events that might also be induced by the Nps, qPCR studies were carried out on Jurkat cells. The only change common to all of the moNps was the upregulation of $C D K N 1 A$, a kinase inhibitor involved in the cell cycle. Cell cycle regulation induced by $\mathrm{ZnO}$ Nps has already been described in Jurkat cells through transcriptomic and bioinformatics approaches. ${ }^{13}$ By contrast, in the same work, it was reported that $\mathrm{TiO}_{2} \mathrm{Nps}$ do not produce such effects, possibly due to the tenfold lower $\mathrm{Np}$ concentration used when compared to that employed here and to the different Nps used. Interestingly, the activation of kinases and the upregulation of some cytokines by $\mathrm{ZnO} \mathrm{Nps}$ in Jurkat cells are in agreement with our MAPK and qPCR measurements. ${ }^{13}$

It is known that there are DNA binding sites for the inducible TFs, AP-1, NF-IL-6, and NFKB, in the $I L-8$ promoter sequence..$^{32}$ Hence, the upregulation of $I L-8$ by $\mathrm{Al}_{2} \mathrm{O}_{3}$ and $\mathrm{ZnO}$ Nps could be due to activation of the NFkB pathway. Interestingly, the release of interleukin (IL)- 8 induced by $\mathrm{ZnO}$ and $\mathrm{Al}_{2} \mathrm{O}_{3} \mathrm{Nps}$ has been detected previously in human peripheral blood leukocytes. ${ }^{20}$ Moreover, it has been shown that $\mathrm{ZnO}$ Nps induce the release of other inflammatory cytokines such as IL- 6 , IL- $1 \beta$, and tumor necrosis factor$\alpha,{ }^{20}$ and this could also be related to the activation of NFKB and SAPK/JNK.

The increase in FASN gene expression detected by qPCR, as well as the effects of $\mathrm{Al}_{2} \mathrm{O}_{3} \mathrm{Nps}$ on the p-ERK protein, could be related to a potential carcinogenic effect, as described for estrogens in cancer cells..$^{33}$ Estrogens also upregulate the FASN gene by ERK activation and a similar effect has been observed in activated Jurkat cells. ${ }^{34,35}$ Activated $\mathrm{T}$ cells undergo some metabolic changes common to tumor cells and this may represent a general metabolic reprogramming during cell growth and proliferation. ${ }^{35,36}$ Moreover, upregulation of the $I L-2$ and $B C L 2 A 1$ genes is also associated with lymphocyte activation. ${ }^{37,38}$

$\mathrm{Al}_{2} \mathrm{O}_{3}$ and $\mathrm{TiO}_{2} \mathrm{Nps}$ promote the expression of apoptotic inhibitors like the NAIP or BCL2A1 genes. The upregulation of these genes by the $\mathrm{Al}_{2} \mathrm{O}_{3} \mathrm{Nps}$ could be related to lymphocyte activation and proliferation, while that by the $\mathrm{TiO}_{2}$ Nps could be related to the activation of 
anti-inflammatory cytokines. Interestingly, in a previous study in which human peripheral blood lymphocytes were used, both Nps were shown to increase the proliferation of the cells induced by PHA. ${ }^{39}$

Alternatively, the change in FASN and $R B P 1$ gene expression induced by the $\mathrm{ZnO} \mathrm{Nps}$ (related to lipid metabolism and cholesterol homeostasis) could be related to the induction of apoptosis due to genomic instability and genotoxic stress, as observed in the model for premature aging in mice. ${ }^{40}$ Moreover, the CYP19A1 gene involved in xenobiotic metabolism is upregulated in the presence of $\mathrm{ZnO} \mathrm{Nps}$. Indeed, $\mathrm{ZnO} \mathrm{Nps}$ and $\mathrm{Zn}^{2+}$ ions have a negative effect on macrophage metabo$\operatorname{lism}^{12}$ and they have also been shown to increase the amounts of some enzymes involved in glycolysis and in the pentose phosphate pathway, for example, 6-phosphogluconate dehydrogenase or aldose reductase.

Another consistent finding is the potential DNA damage induced by cellular stress, which is evident here through the induction of $C D K N 1 A, G A D D 45 A$, and $M 2 M D$.

All four moNps tested influence the cell cycle through increased $C D K N 1 A$ gene expression. The interference with the cell cycle and with the genes involved in metabolism, both interconnected events, ${ }^{41}$ seems to represent a common cell response to $\mathrm{Np}$ exposure, irrespective of their size and composition. This could be related to the internalization process described for some nanostructures ${ }^{42}$ or with the DNA repair process. ${ }^{43}$

In summary, we describe several molecular mechanisms induced by selected moNps in a human lymphocyte cell line. Although some Nps could show a safe profile in the standard toxicity tests, for example, $\mathrm{TiO}_{2}$ or $\mathrm{Al}_{2} \mathrm{O}_{3} \mathrm{Nps}$, we have shown here that they can activate the immune system and induce lymphocyte proliferation by the release of some anti-inflammatory cytokines and the expression of antiapoptotic genes. In contrast, $\mathrm{CeO}_{2} \mathrm{Nps}$ showed a safe profile with only minor activation of some signaling proteins, no relevant changes in gene expression, and a safe cytokine profile, while $\mathrm{ZnO} \mathrm{Nps}$ induced xenobiotic stress, release of inflammatory cytokines, and apoptosis. Nevertheless, these observations were made in the experiments carried out in vitro and they should be confirmed in vivo, because the observed pattern of lymphocyte activation could be modified or abolished by other biological mechanisms. For instance, cytotoxicity of the $\mathrm{ZnO} \mathrm{Nps}$ due to release of $\mathrm{Zn}^{2+}$ ion could be modified in vivo by the binding of free ions to several proteins, such as albumin. Moreover, the lymphocyte proliferative effect induced by the $\mathrm{Al}_{2} \mathrm{O}_{3}$ and $\mathrm{TiO}_{2} \mathrm{Nps}$ should be carefully characterized to analyze their potential use, for instance, as adjuvants in vaccines.

\section{Acknowledgments}

We would like to thank Sergio Moya and Plasmachem for providing the nanomaterials. We also thank Andrea HernándezFernández for excellent technical support, Dr Ángel S. Comesaña for the technical qPCR services at the Centro de Apoyo Científico-Tecnológico a la Investigación, and Dr Luiz Stark for reading the manuscript and for his helpful comments. This work was supported by the Health Impact of Engineered Metal and Metal Oxide Nanoparticles: Response, Bioimaging and Distribution at Cellular and Body Level project (228825, FP7-NMP-SMALL-2) and the Xunta de Galicia (INBIOMED 2012/273, DXPCTSUG-FEDER, Grupo de Potencial de Crecimiento GPC2013-005). We also thank the BIOCAPS project (316265, FP7/REGPOT-2012-2013.1) and acknowledge an Formación de Profesorado Universitario fellowship from the Spanish Ministry of Education to TLF.

\section{Disclosure}

The authors report no conflicts of interest in this work.

\section{References}

1. Gupta AK, Naregalkar RR, Vaidya VD, Gupta M. Recent advances on surface engineering of magnetic iron oxide nanoparticles and their biomedical applications. Nanomedicine. 2007;2(1):23-39.

2. Karimi Z, Karimi L, Shokrollahi H. Nano-magnetic particles used in biomedicine: Core and coating materials. Mater Sci Eng C Mater Biol Appl. 2013;33(5):2465-2475.

3. Premanathan M, Karthikeyan K, Jeyasubramanian K, Manivannan G. Selective toxicity of $\mathrm{ZnO}$ nanoparticles toward Gram-positive bacteria and cancer cells by apoptosis through lipid peroxidation. Nanomedicine. 2011;7(2):184-192.

4. Singh N, Cohen CA, Rzigalinski BA. Treatment of neurodegenerative disorders with radical nanomedicine. Ann N Y Acad Sci. 2007;1122:219-230.

5. Sanvicens N, Marco MP. Multifunctional nanoparticles - properties and prospects for their use in human medicine. Trends Biotechnol. 2008; 26(8):425-433.

6. Schubert D, Dargusch R, Raitano J, Chan S-W. Cerium and yttrium oxide nanoparticles are neuroprotective. Biochem Biophys Res Commun. 2006;342(1):86-91.

7. Pisarek M, Roguska A, Kudelski A, Andrzejczuk M, Janik-Czachor M, Kurzydłowski KJ. The role of Ag particles deposited on $\mathrm{TiO}_{2}$ or $\mathrm{Al}_{2} \mathrm{O}_{3}$ self-organized nanoporous layers in their behavior as SERS-active and biomedical substrates. Mater Chem Phys. 2013;139(1):55-65.

8. Hu X, Cook S, Wang P, Hwang H-m. In vitro evaluation of cytotoxicity of engineered metal oxide nanoparticles. Sci Total Environ. 2009; 407(8):3070-3072.

9. Auffan Ml, Achouak W, Rose Jr, et al. Relation between the redox state of iron-based nanoparticles and their cytotoxicity toward Escherichia coli. Environ Sci Technol. 2008;42(17):6730-6735.

10. Auffan M, Rose J, Wiesner MR, Bottero J-Y. Chemical stability of metallic nanoparticles: A parameter controlling their potential cellular toxicity in vitro. Environ Pollut. 2009;157(4):1127-1133. 
11. Karlsson HL, Gustafsson J, Cronholm P, Möller L. Size-dependent toxicity of metal oxide particles - A comparison between nano- and micrometer size. Toxicol Lett. 2009;188(2):112-118.

12. Triboulet S, Aude-Garcia C, Armand L, et al. Analysis of cellular responses of macrophages to zinc ions and zinc oxide nanoparticles: a combined targeted and proteomic approach. Nanoscale. 2014;6(11):6102-6114.

13. Tuomela S, Autio R, Buerki-Thurnherr T, et al. Gene expression profiling of immune-competent human cells exposed to engineered zinc oxide or titanium dioxide nanoparticles. PLoS One. 2013;8(7):e68415.

14. Huang C-C, Aronstam RS, Chen D-R, Huang Y-W. Oxidative stress, calcium homeostasis, and altered gene expression in human lung epithelial cells exposed to $\mathrm{ZnO}$ nanoparticles. Toxicol In Vitro. 2010;24(1): 45-55.

15. Verstraelen S, Remy S, Casals E, et al. Gene expression profiles reveal distinct immunological responses of cobalt and cerium dioxide nanoparticles in two in vitro lung epithelial cell models. Toxicol Lett. 2014; 228(3):157-169.

16. Johnson GL, Lapadat R. Mitogen-activated protein kinase pathways mediated by ERK, JNK, and p38 protein kinases. Science. 2002; 298(5600):1911-1912.

17. Xia Z, Dickens M, Raingeaud J, Davis RJ, Greenberg ME. Opposing effects of ERK and JNK-p38 MAP kinases on apoptosis. Science. 1995; 270(5240):1326-1331

18. Rayet B, Gélinas C. Aberrant rel/nfkb genes and activity in human cancer. Oncogene. 1999;18(49):6938-6947.

19. Lozano T, Rey M, Rojas E, et al. Cytotoxicity effects of metal oxide nanoparticles in human tumor cell lines. J Phys Conf Ser. 2011;304(1): 012046.

20. Simón-Vázquez R, Lozano-Fernández T, Dávila-Grana A, GonzálezFernández Á. Analysis of the activation routes induced by different metal oxide nanoparticles on human lung epithelial cells. Future Sci OA. 2016;2(2).

21. Buerki-Thurnherr T, Xiao LS, Diener L, et al. In vitro mechanistic study towards a better understanding of $\mathrm{ZnO}$ nanoparticle toxicity. Nanotoxicology. 2013;7(4):402-416.

22. Xia T, Kovochich M, Liong M, et al. Comparison of the mechanism of toxicity of zinc oxide and cerium oxide nanoparticles based on dissolution and oxidative stress properties. ACS Nano. 2008;2(10): 2121-2134.

23. Bai $\mathrm{W}$, Zhang Z, Tian W, et al. Toxicity of zinc oxide nanoparticles to zebrafish embryo: a physicochemical study of toxicity mechanism. J Nanopart Res. 2010;12(5):1645-1654.

24. Cho W-S, Duffin R, Poland CA, et al. Differential pro-inflammatory effects of metal oxide nanoparticles and their soluble ions in vitro and in vivo; zinc and copper nanoparticles, but not their ions, recruit eosinophils to the lungs. Nanotoxicology. 2012;6(1):22-35.

25. Adachi K, Davis MM. T-cell receptor ligation induces distinct signaling pathways in naive vs. antigen-experienced T cells. Proc Natl Acad Sci. 2011;108(4):1549-1554.

26. Simón-Vázquez R, Lozano-Fernández T, Peleteiro-Olmedo M, González-Fernández Á. Conformational changes in human plasma proteins induced by metal oxide nanoparticles. Colloids Surf B Biointerfaces. 2014;113:198-206.

27. Bian S-W, Mudunkotuwa IA, Rupasinghe T, Grassian VH. Aggregation and dissolution of $4 \mathrm{~nm} \mathrm{ZnO}$ nanoparticles in aqueous environments: influence of $\mathrm{pH}$, ionic strength, size, and adsorption of humic acid. Langmuir. 2011;27(10):6059-6068.
28. Reed RB, Ladner DA, Higgins CP, Westerhoff P, Ranville JF. Solubility of nano-zinc oxide in environmentally and biologically important matrices. Environ Toxicol Chem. 2012;31(1):93-99.

29. Tournier C, Hess P, Yang DD, et al. Requirement of JNK for stressinduced activation of the cytochrome c-mediated death pathway. Science. 2000;288(5467):870-874.

30. Baek M, Chung H-E, Yu J, et al. Pharmacokinetics, tissue distribution, and excretion of zinc oxide nanoparticles. Int J Nanomedicine. 2012;7:3081-3097.

31. Kanno T, Siebenlist U. Activation of nuclear factor-kappaB via T cell receptor requires a Raf kinase and $\mathrm{Ca} 2+$ influx. Functional synergy between Raf and calcineurin. J Immunol. 1996;157(12):5277-5283.

32. Roebuck KA. Regulation of interleukin-8 gene expression. J Interferon Cytokine Res. 1999;19(5):429-438.

33. Santolla MF, Lappano R, De Marco P, et al. G protein-coupled estrogen receptor mediates the up-regulation of fatty acid synthase induced by $17 \beta$-estradiol in cancer cells and cancer-associated fibroblasts. $J$ Biol Chem. 2012;287(52):43234-43245.

34. Carr EL, Kelman A, Wu GS, et al. Glutamine uptake and metabolism are coordinately regulated by ERK/MAPK during T lymphocyte activation. J Immunol. 2010;185(2):1037-1044.

35. Wang R, Dillon CP, Shi LZ, et al. The transcription factor Myc controls metabolic reprogramming upon $\mathrm{T}$ lymphocyte activation. Immunity. 2011;35(6):871-882.

36. Vander Heiden MG, Cantley LC, Thompson CB. Understanding the Warburg effect: the metabolic requirements of cell proliferation. Science. 2009;324(5930):1029-1033.

37. Rasooly R, Schuster GU, Gregg JP, Xiao J-H, Chandraratna RAS, Stephensen CB. Retinoid X receptor agonists increase Bcl2al expression and decrease apoptosis of naive T lymphocytes. J Immunol. 2005; 175(12):7916-7929.

38. Wang M, Windgassen D, Papoutsakis E. Comparative analysis of transcriptional profiling of $\mathrm{CD} 3+, \mathrm{CD} 4+$ and $\mathrm{CD} 8+\mathrm{T}$ cells identifies novel immune response players in T-cell activation. BMC Genomics. 2008;9(1):225.

39. Lozano-Fernandez T, Ballester-Antxordoki L, Perez-Temprano N, et al. Potential impact of metal oxide nanoparticles on the immune system: the role of integrins, L-selectin and the chemokine receptor CXCR4. Nanomedicine. 2014;10(6):1301-1310.

40. Park JY, Cho MO, Leonard S, et al. Homeostatic imbalance between apoptosis and cell renewal in the liver of premature aging Xpd mice. PLoS One. 2008;3(6):e2346.

41. Krylov SN, Zhang Z, Chan NWC, Arriaga E, Palcic MM, Dovichi NJ. Correlating cell cycle with metabolism in single cells: combination of image and metabolic cytometry. Cytometry. 1999;37(1):14-20.

42. Zhang TT, Stilwell JL, Gerion D, et al. Cellular effect of high doses of silica-coated quantum dot profiled with high throughput gene expression analysis and high content cellomics measurements. Nano Lett. 2006;6(4):800-808.

43. Cazzalini O, Scovassi AI, Savio M, Stivala LA, Prosperi E. Multiple roles of the cell cycle inhibitor p21CDKN1A in the DNA damage response. Mutat Res-Rev Mutat. 2010;704(1-3):12-20. 


\section{Supplementary materials}

Nanoparticles were analyzed by transmission electron microscopy and DLS in different media (Figure S1).

The Western blot images quantified in Figure 1 (Figure S2), cells incubated with a tenfold lower $\mathrm{Np}$ concentration
(Figure S3) or with three different concentrations of $\mathrm{Zn}^{2+}$ ions (Figure S4) are shown.
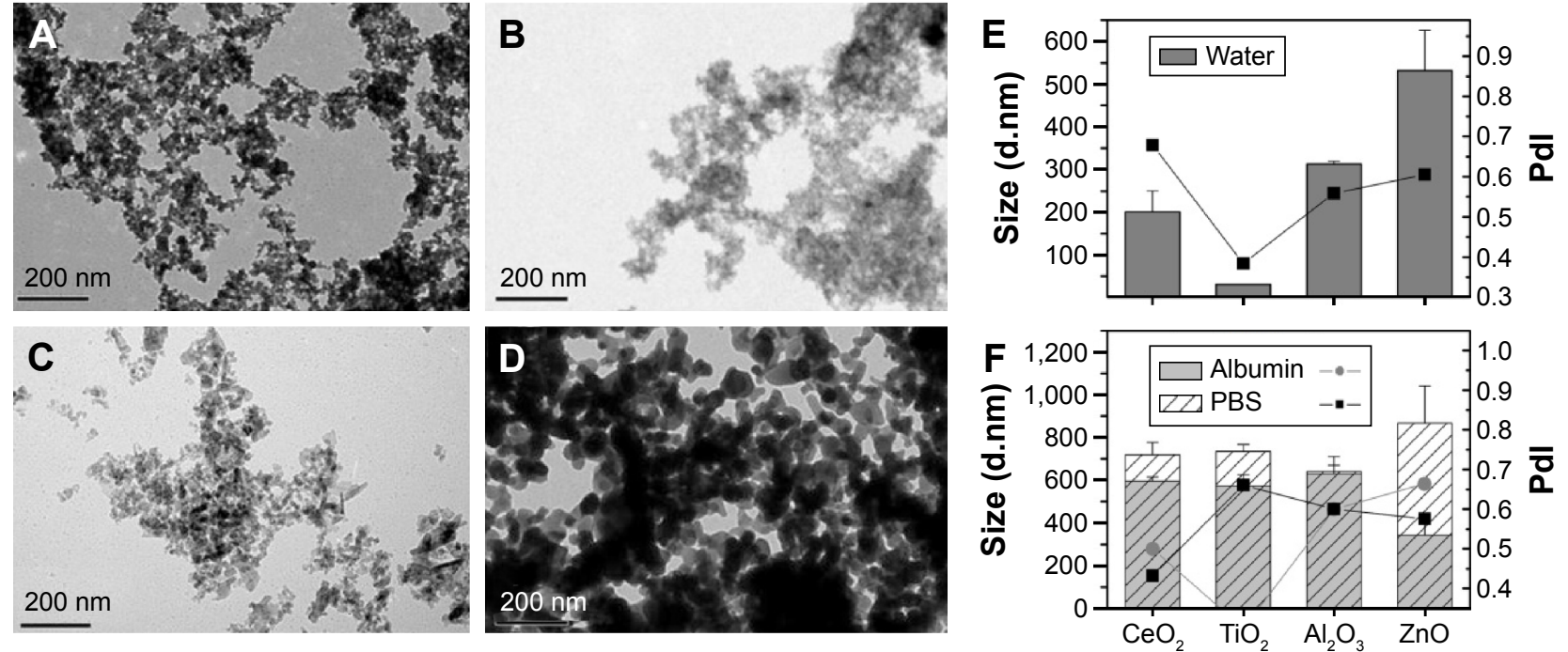

Figure SI TEM images of uncoated $\mathrm{CeO}_{2}, \mathrm{TiO}_{2}, \mathrm{Al}_{2} \mathrm{O}_{3}$, and $\mathrm{ZnO} \mathrm{Nps}$ in water (A-D). DLS measurements of the four $\mathrm{Nps}$ in water (E) and in PBS pH 7.4 or with albumin at $400 \mu \mathrm{g} / \mathrm{mL}$ prepared in PBS (F).

Notes: The diameter of the Np aggregates, determined by intensity distribution, and the Pdl are represented. Standard deviation is shown in error bars ( $\mathrm{n}=4$ ). Reprinted from Colloids Surf B Biointerfaces, I I 3, Simón-Vázquez R, Lozano-Fernández T, Peleteiro-Olmedo M, González-Fernández Á, Conformational changes in human plasma proteins induced by metal oxide nanoparticles, 198-206, Copyright 2016, with permission from Elsevier.'

Abbreviations: DLS, dynamic light scattering; Nps, nanoparticles; PBS, phosphate-buffered saline; Pdl, polydispersity index; TEM, transmission electron microscopy. 
$1 \mathrm{~h}$
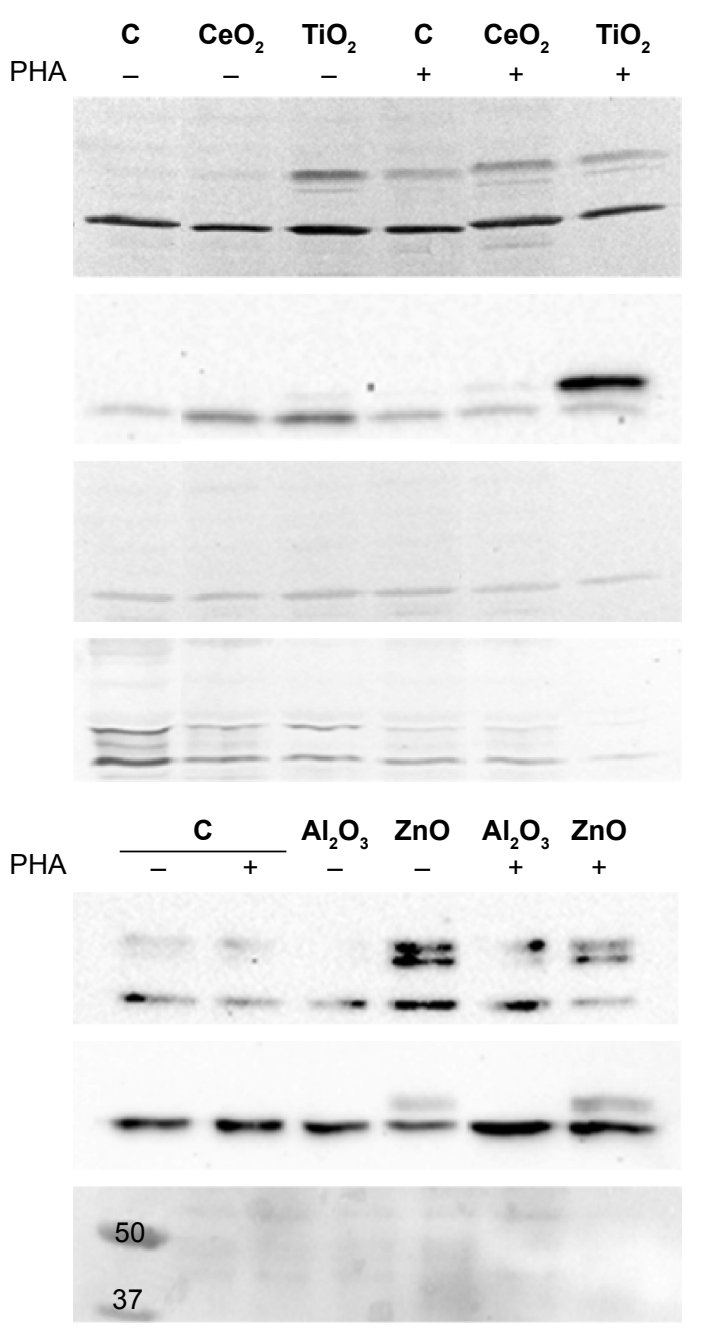

37

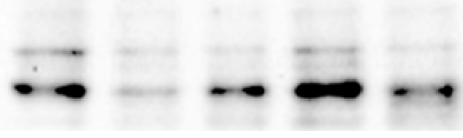

$3 \mathrm{~h}$

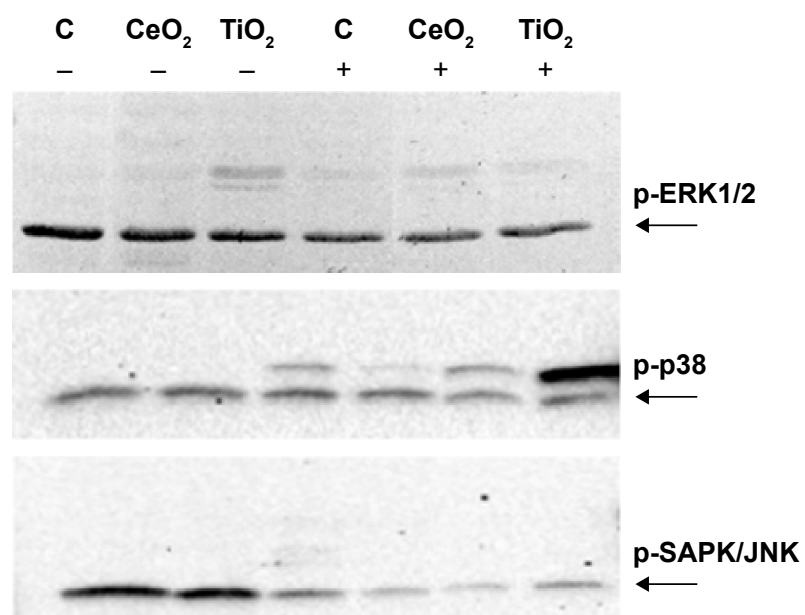

$\mathrm{IKB} \alpha$

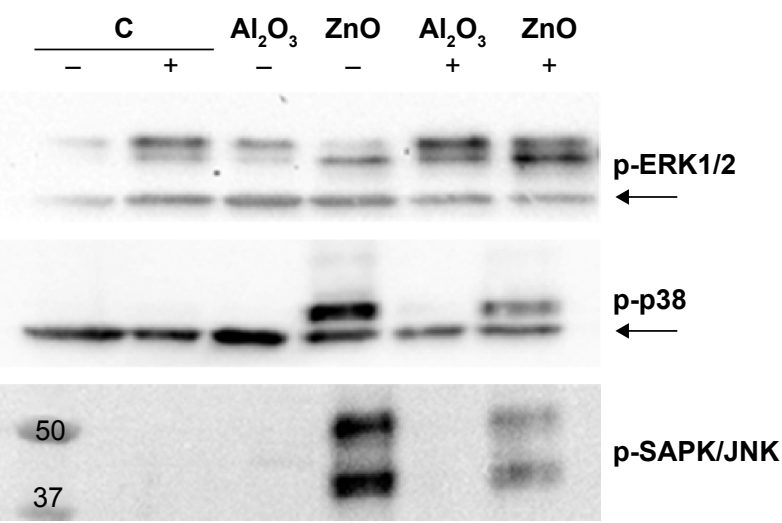

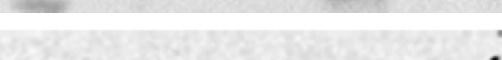

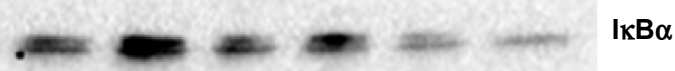

Figure S2 Western blot showing the expression of p-ERK (I,2), p-p38, p-SAPK/JNK, and IkB $\alpha$ in Jurkat cells, either untreated (control cells, C) or treated with $100 \mu \mathrm{g} / \mathrm{mL}$ $\mathrm{CeO}_{2}, \mathrm{TiO}_{2}, \mathrm{Al}_{2} \mathrm{O}_{3}$, and $50 \mu \mathrm{g} / \mathrm{mL} \mathrm{ZnO} \mathrm{Nps}$.

Note: Cells were prestimulated (+PHA) or not (-PHA) with PHA.

Abbreviations: ERK, extracellular signal-regulated kinase; $h$, hour; I $\mathrm{K} \alpha$, nuclear factor kappa-light-chain-enhancer of the activated B-cell inhibitor; JNK, c-Jun aminoterminal kinase; Nps, nanoparticles; PHA, phytohemagglutinin; SAPK, stress-activated protein kinase. 


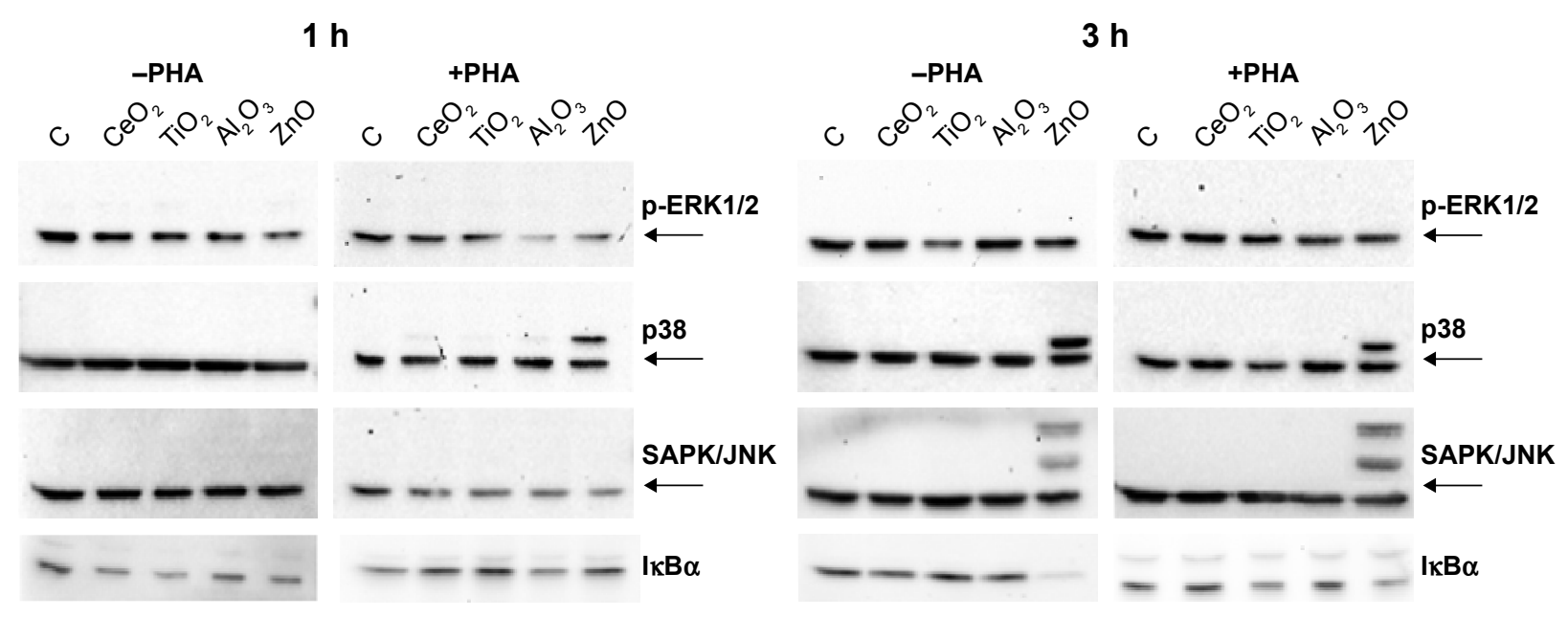

Figure S3 Activation of ERK $(I, 2), p 38, S A P K / J N K$, and degradation of $\mathrm{I} \kappa \mathrm{B} \alpha$, the $\mathrm{NFKB}$ inhibitor, in Jurkat cells in the presence of $\mathrm{CeO}$, $\mathrm{TiO}_{2}$, $\mathrm{Al} \mathrm{O}_{3}$, and $\mathrm{ZnO}$ nanoparticles.

Notes: Jurkat cells, prestimulated (+PHA) or not (-PHA) with PHA, were incubated with $\mathrm{CeO}_{2}, \mathrm{TiO}_{2}$, or $\mathrm{Al}_{2} \mathrm{O}_{3} \mathrm{Nps}_{(\mathrm{all}}$ at $\left.\mathrm{I0} \mu \mathrm{g} / \mathrm{mL}\right)$ and $\mathrm{ZnO} \mathrm{Nps}(\mathrm{at} 5 \mu \mathrm{g} / \mathrm{mL})$ at two different times ( $I$ and 3 hours). GAPDH was used as a loading control (indicated by arrows).

Abbreviations: ERK, extracellular signal-regulated kinase; GAPDH, glyceraldehyde 3-phosphate dehydrogenase; h, hour; IKB $\alpha$, NFKB inhibitor; JNK, c-Jun amino-terminal kinase; NFKB, nuclear factor kappa-light-chain-enhancer of the activated B-cell; Nps, nanoparticles; PHA, phytohemagluttinin; SAPK, stress-activated protein kinase.

$1 \mathrm{~h}$

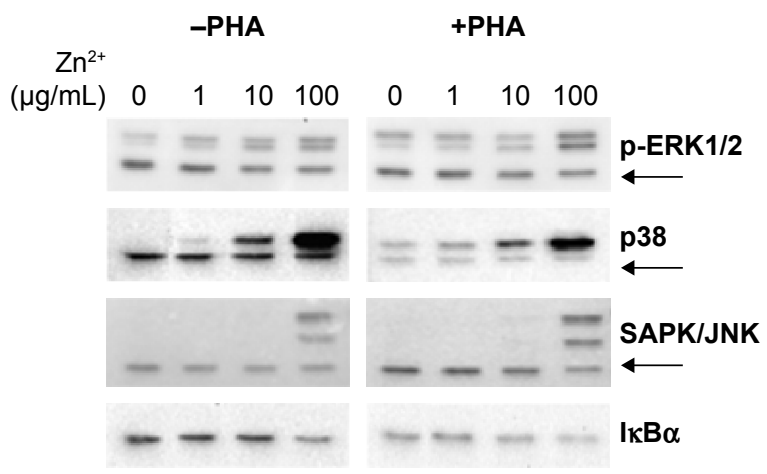

$3 \mathbf{h}$

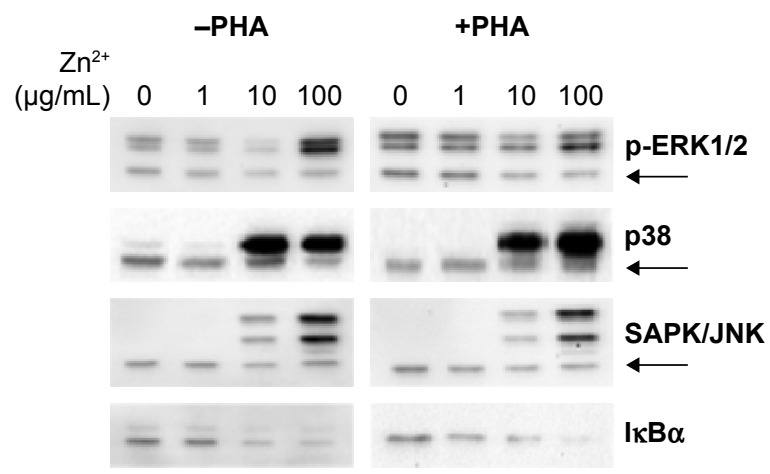

Figure S4 Activation of ERK (I,2), p38, SAPK/JNK, and IKB $\alpha$ induced by the $\mathrm{Zn}^{2+}$ ions in Jurkat cells.

Note: The $\mathrm{Zn}^{2+}$ ions were tested at three different concentrations (I, 10 , and $100 \mu \mathrm{g} / \mathrm{mL}$ ), and in the presence of absence of PHA.

Abbreviations: ERK, extracellular signal-regulated kinase; $h$, hour; I $\mathrm{K} \mathrm{B} \alpha$, nuclear factor kappa-light-chain-enhancer of the activated B-cell inhibitor; JNK, c-Jun aminoterminal kinase; Nps, nanoparticles; PHA, phytohemagluttinin; SAPK, stress-activated protein kinase.

\section{Reference}

1. Simón-Vázquez R, Lozano-Fernández T, Peleteiro-Olmedo M, GonzálezFernández Á. Conformational changes in human plasma proteins induced by metal oxide nanoparticles. Colloids Surf B Biointerfaces. 2014;113:198-206.

\section{Publish your work in this journal}

The International Journal of Nanomedicine is an international, peerreviewed journal focusing on the application of nanotechnology in diagnostics, therapeutics, and drug delivery systems throughout the biomedical field. This journal is indexed on PubMed Central, MedLine, CAS, SciSearch ${ }^{\circledR}$, Current Contents ${ }^{\circledR} /$ Clinical Medicine,
Journal Citation Reports/Science Edition, EMBase, Scopus and the Elsevier Bibliographic databases. The manuscript management system is completely online and includes a very quick and fair peer-review system, which is all easy to use. Visit http://www.dovepress.com/ testimonials.php to read real quotes from published authors. 